\title{
Hematological profile, total plasma protein and fibrinogen concentrations of clinically healthy adult Campeiro horses
}

\author{
Perfil hematológico, concentração de proteínas totais e fibrinogênio \\ plasmático de equinos adultos e clinicamente sadios da raça Campeiro
}

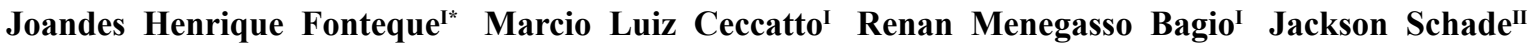

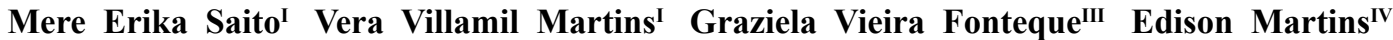 \\ Alexandre Floriani Ramos ${ }^{\mathrm{V}}$ Maria do Socorro Maués Albuquerque ${ }^{\mathrm{V}}$ Dirceu Costa $^{\mathrm{VI}}$
}

\section{ABSTRACT}

This research was performed by a multidisciplinary and interagency team and sought to determine the blood profile, total plasma protein and fibrinogen concentrations of clinically healthy adult Campeiro horses. A total of 138 horses (14 stallions, 74 non-pregnant and 50 pregnant mares) over three years of age from breeders located in the states of Santa Catarina and Rio Grande do Sul were divided into groups according to age, sex and pregnancy status. Statistical analysis of the data was performed using the ANOVA test, Student's T test, and descriptive analyses $(P<0.05)$. There was a significant difference $(P<0.05)$ in the values for $\mathrm{MCV}, \mathrm{MCH}$, and total number of eosinophiles when comparing different age groups. There was also a notable difference $(P<0.05)$ in the total plasma protein and total number of eosinophile variables when comparing pregnant females to nonpregnant females. These results show that the Campeiro breed presents certain peculiarities regarding variables in the complete blood count, total plasma protein and fibrinogen compared to the values described by other authors for other breeds. Thus, it is suggested that the values established in this study should be used as benchmarks for interpreting erythrocyte and leukocyte counts when evaluating these variables in Campeiro horses.

Key words: campeiro, horses, $C B C$, total plasma protein.

RESUMO

O presente trabalho foi executado por uma equipe multidisciplinar e interinstitucional, objetivando determinar o perfil hematológico, a concentração de proteinas totais e o fibrinogênio plasmático de equinos adultos e clinicamente sadios da raça Campeiro. Foram utilizados 138 animais (14 machos inteiros, 74 fêmeas vazias e 50 prenhes), com idades acima de três anos, provenientes de criatórios localizados em Santa Catarina e Rio Grande do Sul, divididos em grupos de acordo com a idade, sexo e estado gestacional. A análise estatística dos dados foi realizada por meio do teste ANOVA, teste t de Student e análise descritiva $(P<0,05)$. Houve diferença significativa $(P<0,05)$ para os valores do HCM, VCM e número total de eosinófilos, quando comparadas as diferentes faixas etárias. Também houve diferença $(P<0,05)$ para as variáveis PTP e número total de eosinófilos, quando comparadas fêmeas prenhas e vazias. A partir desses resultados, pode-se concluir que os equinos Campeiros apresentam particularidades com relação às variáveis do hemograma, proteínas totais e fibrinogênio plasmático, quando comparados aos descritos por outros autores em outras raças. Sendo assim, sugere-se que os valores estabelecidos no presente estudo sejam tomados como valores de referência na interpretação do eritrograma e leucograma para a avaliação dessas variáveis em equinos da raça Campeiro.

Palavras-chave: campeiro, equino, hemograma, proteina total plasmática

\section{INTRODUCTION}

The locally adapted breeds of horses were subjected for a prolonged period of time to natural selection within certain environments, to the point of presenting characteristics that are specific to these conditions (BICALHO, 1985). Notable

\footnotetext{
'Departamento de Medicina Veterinária, Centro de Ciências Agroveterinárias (CAV), Universidade do Estado de Santa Catarina (UDESC), Av. Luiz de Camões, 2090, Bairro Conta Dinheiro, 88520-000, Lages, SC, Brasil. E-mail: fonteque@hotmail.com. "Corresponding author. ${ }^{I}$ Departamento de Clínicas Veterinárias, Universidade Estadual de Londrina (UEL), Londrina, PR, Brasil.

"IICentro Universitário Facvest (UNIFACVEST), Lages, SC, Brasil.

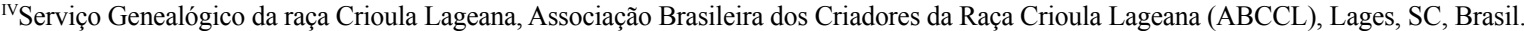

${ }^{v}$ Embrapa Recursos Genéticos e Biotecnologia, Parque Estação Biológica (PqEB), Brasília, DF, Brasil.

${ }^{\mathrm{V}}$ Serviço de Registro Genealógico da raça Campeiro, Associação Brasileira dos Criadores de Cavalo Campeiro (ABRACCC), Lages, SC, Brasil. Received 09.20.14 Approved 05.19.15 Returned by the author 08.26.15
} CR-2014-1408.R2 
among these breeds, in Brazil, is the Campeiro horse, which descended from the animals brought during the Spanish expeditions of Alvar Nuñez (Cabeza de Vaca) in March 1541 (ARAÚJO, 1990; ABRACCC, 2013). The Campeiro horse breeding, which were once abundant throughout the highlands of Santa Catarina and Rio Grande do Sul as well as the Campos Gerais region in Paraná, is currently limited to the cities of Lages and Curitibanos, both in the highland region of Santa Catarina (ARAÚJO, 1990). In 1976, the Brazilian Association of Campeiro Horse Breeders (ABRACCC) was founded, and in mid1985, the Campeiro breed was officially recognized by the Ministry of Agriculture, and the "Herd Book" was created, with the Official Genealogical Registry Service for the Breed. Campeiro horses are considered suitable for riding and pulling light loads due to their morphometric characteristics (McMANUS et al., 2005). These horses possess good endurance and are often used for herding cattle.

Ascertainment baselines for hematology, total plasma protein and fibrinogen concentrations are important and essential for identifying the breed's physiological benchmarks and the variations therein, as well as for the correct interpretation of laboratory tests used to help diagnose diseases (BALARIN et al., 2005). Given that factors such as handling, physiological status, temperament, breed, and age can influence the hematological values of horses, it is important to establish reliable benchmarks (HARVEY et al., 1984;. RALSTON; NOCKELS \& SQUIRES, 1988; DOSSIN, 1993; TAYLOR-MACALLISTER, 1997; MARTINS et al., 2005; LACERDA et al., 2006). However, research dealing with the hematological evaluation of Campeiro horses is non-existent. This study seeks to determine the $\mathrm{CBC}$, total plasma protein and fibrinogen concentration profile for adult Campeiro horses, male and female, to standardize baseline values for use in the hematological evaluations of these horses.

\section{MATERIAL AND METHODS}

This research project was undertaken by a multidisciplinary and inter-institutional team involving the Santa Catarina State University (UDESC), the National Center for Genetic Resources and Biotechnology (CENARGEN) of the Brazilian Agricultural Research Corporation (Embrapa), Facvest University and the Brazilian Association of Campeiro Horse Breeders (ABRACCC). A total of 138 Campeiro horses were used in this study, of which 14 were males (stallions) and 124 were females, including 74 non-pregnant females and 50 pregnant females. All of these horses were registered in ABRACCC and came from conservation centers located in the cities of Lages, Curitibanos, Campos Novos, Concordia - SC and Caxias do Sul - RS. The animals were grouped according to gender, pregnancy status (pregnant and non-pregnant mares) and age, for which there were four groups: between 3 and 5 years old, between 6 and 8 years old, between 9 and 12 years old and over 13 years old. Blood samples were collected from each horse via jugular venipuncture and placed in vacuum tubes containing 10\% EDTA anticoagulant (Vacutainer K3 Hemogard $^{\circledR}$ Systems, Becton Dickinson, England). Tests to ascertain the complete blood count, total plasma protein and fibrinogen concentrations were performed at the Laboratory of Clinical Pathology of the Veterinary University Hospital (HCV) of CAV-UDESC in Lages - SC. For the red blood cell and white blood cell counts, a hemocytometric technique was used in a Neubauer chamber, and for the differential leukocyte count, blood smears were produced and treated with a rapid panoptic reagent, with subsequent analysis by optical microscopy (JAIN, 1993). Concentration of hemoglobin (Hb) was determined through a colorimetric test using Theratio Plate ${ }^{\circledR}$ Tpanalyzer electronic equipment and a Bioclin ${ }^{\circledR}$ reagent kit. The packed cell volume (PCV) was determined using the microhematocrit method to ascertain the mean corpuscular volume (MCV), mean corpuscular hemoglobin (MCH) and mean corpuscular hemoglobin concentration (MCHC) by the technique described by JAIN (1993). The total protein concentration (TPC) of the plasma was ascertained using refractometry method (ATTAGO Co. refractometer), and plasma fibrinogen concentration was tested using heat precipitation method described by JAIN (1993). Statistical analysis of the data was performed using repeated measures analysis of variance (ANOVA) test, Student's t test for the comparison of the means and a descriptive data analysis, assuming a probability of error of $5 \%$ according to CURI (1998).

\section{RESULTS AND DISCUSSION}

The mean values, standard deviation, minimum and maximum values of erythrogram, leukocyte count, total protein concentration and plasma fibrinogen variables of 138 Campeiro horses are shown in table 1. Reference intervals currently

Ciência Rural, v.46, n.1, jan, 2016. 
Table 1 - Mean values, standard deviations $(x+s)$, maximum and minimum values for number of erythrocytes (Erythro), hemoglobin concentration (Hemog), hematocrit (PCV), mean corpuscular volume (MCV), mean corpuscular hemoglobin (MCH) mean corpuscular hemoglobin concentration (MCHC), total plasma protein (TPP), plasma fibrinogen (Fib), total number of leukocytes (Leuco), segmented neutrophils (Seg), band cells (Band), lymphocytes (Lympho), monocytes (Mono), eosinophils (Eosi), basophils (Baso) and neutrophil: lymphocyte ratio $(\mathrm{N}: \mathrm{L})$ for 138 male $(\mathrm{n}=14)$ and female $(\mathrm{n}=124)$ adult Campeiro horses.

\begin{tabular}{|c|c|c|c|c|}
\hline Variables & Mean & Standard deviations & Maximun V. & Minimum $\mathrm{V}$. \\
\hline Erythro $\left(10^{6} \mu \mathrm{L}^{-1}\right)$ & 7.78 & 1.09 & 11.12 & 5.81 \\
\hline Hemog $\left(\mathrm{g} \mathrm{dL}^{-1}\right)$ & 12.29 & 1.63 & 16.79 & 9.56 \\
\hline $\operatorname{PCV}(\%)$ & 36.10 & 3.88 & 47.00 & 30.00 \\
\hline MCV (fL) & 47.07 & 5.25 & 58.30 & 34.17 \\
\hline $\mathrm{MCH}(\mathrm{pg})$ & 15.98 & 2.26 & 20.36 & 11.30 \\
\hline $\operatorname{MCHC}\left(\mathrm{g} \mathrm{dL}^{-1}\right)$ & 34.03 & 2.34 & 42.94 & 30.44 \\
\hline $\mathrm{TPP}\left(\mathrm{g} \mathrm{dL}^{-1}\right)$ & 7.03 & 0.54 & 8.20 & 5.40 \\
\hline Fib $\left(\mathrm{mg} \mathrm{dL}^{-1}\right)$ & 348.08 & 99.98 & 500.00 & 200.00 \\
\hline Leuco $\left(x 103 \mu \mathrm{L}^{-1}\right)$ & 10.70 & 1.78 & 14.20 & 6.55 \\
\hline $\operatorname{Seg}\left(x 10^{3} \mu \mathrm{L}^{-1}\right)$ & 5.38 & 1.46 & 8.57 & 1.77 \\
\hline Band $\left(x 10^{3} \mu \mathrm{L}^{-1}\right)$ & 0.00 & 0.00 & 0.00 & 0.00 \\
\hline Lympho $\left(\mathrm{x} 10^{3} \mu \mathrm{L}^{-1}\right)$ & 4.58 & 1.00 & 6.81 & 2.06 \\
\hline Mono $\left(\times 10^{3} \mu \mathrm{L}^{-1}\right)$ & 0.11 & 0.10 & 0.37 & 0.00 \\
\hline $\operatorname{Eosi}\left(\times 10^{3} \mu \mathrm{L}^{-1}\right)$ & 0.59 & 0.53 & 2.84 & 0.00 \\
\hline Baso $\left(x 10^{3} \mu \mathrm{L}^{-1}\right)$ & 0.01 & 0.03 & 0.12 & 0.00 \\
\hline $\mathrm{N}: \mathrm{L}$ & 1.24 & 0.47 & 2.67 & 0.39 \\
\hline
\end{tabular}

used for the interpretation of the $\mathrm{CBC}$ in horses are determined using values obtained from animals of different breeds and thus may be unrepresentative of values specific to a certain breed (LATIMER \& PRASSE, 2003), such as the Campeiro. VEIGA et al. (2006), when evaluating horses of the Crioula breed, obtained mean values similar to the ones found in this study for the erythrocyte and leukocyte variables; however, there were differences of significant magnitude in the maximum and minimum values of these variables. In a study of the Mangalarga Marchador breed, HOLANDA et al. (2013) obtained higher values for the erythrocyte variables except for the MCV. Notably, in horses of the Campeiro breed, the number of erythrocytes, $\mathrm{PCV}$ and $\mathrm{Hb}$ variables had lower mean values and the MCV and MCHC variables had higher mean values than the findings of COSTA et al. (2009) in the Purebred Iberian Horse breed. SILVA (2011) showed higher values for erythrocyte variables, including $\mathrm{MCV}$ and $\mathrm{MCH}$ and lower values for the MCHC, in horses of the Lusitano breed than the values found in this study. According to GRONDIN \& DEWITT (2010), warm-blooded horses such as the Iberian Purebred and Lusitano show higher values for erythrocyte variables except for the MCV. The same author observed significantly lower values for the number of erythrocytes, $\mathrm{Hb}$, $\mathrm{MCHC}$, and total number of monocytes variables than the erythrocyte and leukocyte count data reported in the literature for the Iberian Purebred and other warm-blooded breeds. However, significantly higher values were ascertained for $\mathrm{MCV}$, PCV, $\mathrm{MCH}$, total leukocytes, neutrophils, lymphocytes and eosinophils variables (SILVA, 2011). These results substantiate the observations from other authors that hematological values are affected by factors such as breed and temperament (HARVEY et al., 1984; RALSTON et al., 1988; DOSSIN, 1993; JAIN, 1993; TAYLOR-MACALLISTER, 1997; MARTINS et al., 2005; LACERDA et al., 2006).

Mean values for the concentration of total protein and fibrinogen in the plasma (Table 1) of 138 Campeiro horses are within the reference range for the equine species according to KANEKO et al. (2008). However, we noted that the maximum value of the fibrinogen concentration exceeded the range proposed by those authors, suggesting that breeding may affect this variable.

There was no significant difference $(\mathrm{P}>0.05)$ in the erythrocyte and leukocyte variables between the males and females of the Campeiro breed (Table 2). These results are consistent with the findings of LACERDA et al. (2006) and RIBEIRO et al. (2008) in high-performance breeds (Iberian Purebred, Brazilian Sport Horse, and Crioula) and the Pantaneiro breed, respectively. Gender influences on hematological values have been observed by other authors with other breeds (VEIGA et al., 2006; 
Table 2 - Mean values, standard deviations $(x+s)$, maximum and minimum values for number of erythrocytes (Erythro), hemoglobin concentration (Hemog), hematocrit (PCV), mean corpuscular volume (MCV), mean corpuscular hemoglobin (MCH) mean corpuscular hemoglobin concentration (MCHC), total plasma protein (TPP), plasma fibrinogen (Fib), total number of leukocytes (Leuco), segmented neutrophils (Seg), band cells (Band), lymphocytes (Lympho), monocytes (Mono), eosinophils (Eosi), basophils (Baso) and neutrophil: lymphocyte ratio $(\mathrm{N}$ : L) for male $(\mathrm{n}=14)$ and female $(\mathrm{n}=124)$, non-pregnant $(\mathrm{n}=74)$ and pregnant $(\mathrm{n}=50)$, Campeiro horses.

\begin{tabular}{|c|c|c|c|c|}
\hline Variables & 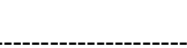 & 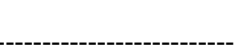 & \multirow{2}{*}{$\begin{array}{c}\text { Female } \\
\text { Non-pregnant }\end{array}$} & \multirow{2}{*}{$\begin{array}{c}\text { Female } \\
\text { Pregnant }\end{array}$} \\
\hline & & & & \\
\hline Erythro $\left(10^{6} \mu \mathrm{L}^{-1}\right)$ & $8.13 \pm 1.21^{\mathrm{a}}$ & $7.74 \pm 1.06^{\mathrm{a}}$ & $7.74 \pm 1.17^{\mathrm{A}}$ & $7.65 \pm 1.02^{\mathrm{A}}$ \\
\hline Hemog $\left(\mathrm{g} \mathrm{dL}^{-1}\right)$ & $13.74 \pm 2.12^{\mathrm{a}}$ & $12.02 \pm 1.47^{\mathrm{a}}$ & $11.77 \pm 1.41^{\mathrm{A}}$ & $12.21 \pm 1.03^{\mathrm{A}}$ \\
\hline PCV (\%) & $38.43 \pm 5.53^{\mathrm{a}}$ & $35.71 \pm 3.53^{\mathrm{a}}$ & $35.28 \pm 3.61^{\mathrm{A}}$ & $36.00 \pm 2.83^{\mathrm{A}}$ \\
\hline MCV (fL) & $47.61 \pm 5.70^{\mathrm{a}}$ & $46.83 \pm 5.20^{\mathrm{a}}$ & $46.33 \pm 5.47^{\mathrm{A}}$ & $47.93 \pm 4.55^{\mathrm{A}}$ \\
\hline MHC (pg) & $16.95 \pm 1.51^{\mathrm{a}}$ & $15.83 \pm 2.33^{\mathrm{a}}$ & $15.49 \pm 2.43^{\mathrm{A}}$ & $16.16 \pm 1.91^{\mathrm{A}}$ \\
\hline $\mathrm{MCHC}\left(\mathrm{g} \mathrm{dL}^{-1}\right)$ & $35.72 \pm 1.26^{\mathrm{a}}$ & $33.63 \pm 2.27^{\mathrm{a}}$ & $33.34 \pm 1.82^{\mathrm{A}}$ & $34.02 \pm 2.93^{\mathrm{A}}$ \\
\hline $\operatorname{TPP}\left(\mathrm{g} \mathrm{dL}^{-1}\right)$ & $7.00 \pm 0.76^{\mathrm{a}}$ & $7.04 \pm 0.50^{\mathrm{a}}$ & $6.84 \pm 0.50^{\mathrm{B}}$ & $7.35 \pm 0.38^{\mathrm{A}}$ \\
\hline Fib $\left(\mathrm{mg} \mathrm{dL}^{-1}\right)$ & $285.71 \pm 89.97^{\mathrm{a}}$ & $362.22 \pm 96.03^{\mathrm{a}}$ & $348.00 \pm 91.83^{\mathrm{A}}$ & $362.50 \pm 114.75^{\mathrm{A}}$ \\
\hline Leuco $\left(\times 10^{3} \mu \mathrm{L}^{-1}\right)$ & $10.49 \pm 1.99^{\mathrm{a}}$ & $10.73 \pm 1.77^{\mathrm{a}}$ & $10.29 \pm 1.93^{\mathrm{A}}$ & $11.25 \pm 1.42^{\mathrm{A}}$ \\
\hline $\operatorname{Seg}\left(\times 10^{3} \mu \mathrm{L}^{-1}\right)$ & $5.52 \pm 2.03^{\mathrm{a}}$ & $5.35 \pm 1.38^{\mathrm{a}}$ & $5.15 \pm 1.58^{\mathrm{A}}$ & $5.70 \pm 1.14^{\mathrm{A}}$ \\
\hline Band $\left(x 10^{3} \mu \mathrm{L}^{-1}\right)$ & $0.00 \pm 0.00^{\mathrm{a}}$ & $0.00 \pm 0.00^{\mathrm{a}}$ & $0.00 \pm 0.00^{\mathrm{A}}$ & $0.00 \pm 0.00^{\mathrm{A}}$ \\
\hline Lympho $\left(\times 10^{3} \mu \mathrm{L}^{-1}\right)$ & $4.48 \pm 1.13^{\mathrm{a}}$ & $4.59 \pm 0.99^{\mathrm{a}}$ & $4.55 \pm 0.99^{\mathrm{A}}$ & $4.53 \pm 1.10^{\mathrm{A}}$ \\
\hline Mono $\left(\mathrm{x} 10^{3} \mu \mathrm{L}^{-1}\right)$ & $0.07 \pm 0.11^{\mathrm{a}}$ & $0.12 \pm 0.10^{\mathrm{a}}$ & $0.10 \pm 0.09^{\mathrm{A}}$ & $0.14 \pm 0.12^{\mathrm{A}}$ \\
\hline $\operatorname{Eosi}\left(\mathrm{x} 10^{3} \mu \mathrm{L}^{-1}\right)$ & $0.41 \pm 0.35^{\mathrm{a}}$ & $0.62 \pm 0.55^{\mathrm{a}}$ & $0.48 \pm 0.45^{\mathrm{B}}$ & $0.86 \pm 0.66^{\mathrm{A}}$ \\
\hline Baso $\left(\times 10^{3} \mu \mathrm{L}^{-1}\right)$ & $0.01 \pm 0.03^{\mathrm{a}}$ & $0.01 \pm 0.04^{\mathrm{a}}$ & $0.02 \pm 0.04^{\mathrm{A}}$ & $0.01 \pm 0.04^{\mathrm{A}}$ \\
\hline $\mathrm{N}: \mathrm{L}$ & $2.45 \pm 0.62^{\mathrm{a}}$ & $2.42 \pm 0.55^{\mathrm{a}}$ & $1.18 \pm 0.44^{\mathrm{A}}$ & $1.35 \pm 0.51^{\mathrm{A}}$ \\
\hline
\end{tabular}

${ }^{A}$ For the same capital letters, there is no significant difference $(\mathrm{P}<0.05)$ between pregnant and non-pregnant females.

${ }^{\mathrm{a}}$ For the same lowercase letters, there is no significant difference $(\mathrm{P}<0.05)$ between males and females.

HOLANDA et al., 2013), showing that this variable is also influenced by race within the equine species. There was no gender influence on total plasma protein and fibrinogen values in Campeiro horses. A similar result was obtained by VEIGA et al. (2006) with the Crioula horses. These results suggest that these variables are less affected by gender.

There was no significant difference in the erythrocyte variables between pregnant and non-pregnant Campeiro mares (Table 2). In analyzing the WBC, statistically higher $(\mathrm{P}>0.05)$ values can be ascertained for only the total number of eosinophils in pregnant Campeiro mares (Table 3). VEIGA et al. (2006) found significantly higher values for the MCV, total number of leukocytes, segmented neutrophils, eosinophils, monocytes and lymphocytes in pregnant Crioula mares.

Regarding the total protein concentration in the Campeiro horses, significantly higher $(\mathrm{P}<0.05)$ values were noted for pregnant mares than nonpregnant mares (Table 2). According to LOPES et al. (2007), during pregnancy, there is usually a decrease in serum albumin concentrations and an increase in globulin concentrations, followed by a decrease during the postpartum period due to the production of colostrum. Increase in globulin concentration due to pregnancy may have contributed to the increase in total protein concentration in pregnant mares.

In table 3 the mean and standard deviation values for the erythrocyte, leukocyte, total plasma protein and fibrinogen variables are shown for each age group. Significantly higher means $(\mathrm{P}<0.05)$ for the variables $\mathrm{MCH}$ and $\mathrm{MCV}$ in the 9 to 12 -year-old group than in the 3 to 5-year-old group are probably associated with lower mean values for number of erythrocytes, although this variable did not differ statistically between age groups. This variation may have been influenced by the increased plasma volume associated with pregnancy (CARRICK \& BEGG, 2008), which is substantiated in this research because a larger number of pregnant females were in the group aged 9-12. DÍAZ et al. (2011), in researching hematological values of Peruvian horses, observed significantly higher mean values for the variables $\mathrm{Hb}$, $\mathrm{MCV}$ and MCHC in adult horses than in horses less than three years old. VEIGA et al. (2006) also found differences between foals up to one year old and freerange adult horses in the variables $\mathrm{Hb}, \mathrm{PCV}$, and $\mathrm{MCV}$, 
Table 3 - Mean values, standard deviations $(\mathrm{x}+\mathrm{s})$, maximum and minimum values for number of erythrocytes (Erythro), hemoglobin concentration (Hemog), hematocrit (PCV), mean corpuscular volume (MCV), mean corpuscular hemoglobin (MCH) mean corpuscular hemoglobin concentration (MCHC), total plasma protein (TPP), plasma fibrinogen (Fib), total number of leukocytes (Leuco), segmented neutrophils (Seg), band cells (Band), lymphocytes (Lympho), monocytes (Mono), eosinophils (Eosi), basophils (Baso) and neutrophil: lymphocyte ratio (N: L) for male and female Campeiro horses aged 3 to 5 years old ( $\mathrm{n}=34$ ), 6 to 8 years old $(n=34), 9$ to 12 years old $(n=34)$ and over 13 years old $(n=36)$.

\begin{tabular}{|c|c|c|c|c|}
\hline Variables & 3 to 5 years & 6 to 8 years & 9 to 12 years & Over 13 years \\
\hline Erythro $\left(10^{6} \mu \mathrm{L}^{-1}\right)$ & $8.00 \pm 1.29^{\mathrm{a}}$ & $8.03 \pm 1.05^{\mathrm{a}}$ & $7.33 \pm 0.98^{\mathrm{a}}$ & $7.75 \pm 1.02^{\mathrm{a}}$ \\
\hline $\operatorname{Hemog}\left(\mathrm{g} \mathrm{dL}^{-1}\right)$ & $11.55 \pm 1.24^{\mathrm{a}}$ & $12.83 \pm 1.85^{\mathrm{a}}$ & $12.42 \pm 1.71^{\mathrm{a}}$ & $12.26 \pm 1.51^{\mathrm{a}}$ \\
\hline PCV $(\%)$ & $34.08 \pm 2.50^{\mathrm{a}}$ & $37.57 \pm 4.50^{\mathrm{a}}$ & $36.23 \pm 4.38^{\mathrm{a}}$ & $36.23 \pm 3.24^{\mathrm{a}}$ \\
\hline MCV (fL) & $43.76 \pm 5.69^{b}$ & $46.94 \pm 4.86^{\mathrm{ab}}$ & $50.23 \pm 4.75^{\mathrm{a}}$ & $46.98 \pm 4.21^{\mathrm{ab}}$ \\
\hline $\mathrm{MCH}(\mathrm{pg})$ & $14.70 \pm 2.39^{\mathrm{b}}$ & $16.11 \pm 2.27^{\mathrm{ab}}$ & $17.08 \pm 2.22^{\mathrm{a}}$ & $15.93 \pm 1.74^{\mathrm{ab}}$ \\
\hline $\operatorname{MCHC}\left(\mathrm{g} \mathrm{dL}^{-1}\right)$ & $33.86 \pm 2.14^{\mathrm{a}}$ & $34.10 \pm 1.85^{\mathrm{a}}$ & $34.29 \pm 2.22^{\mathrm{a}}$ & $33.85 \pm 3.22^{\mathrm{a}}$ \\
\hline $\mathrm{TPP}\left(\mathrm{g} \mathrm{dL}^{-1}\right)$ & $6.91 \pm 0.55^{\mathrm{a}}$ & $6.94 \pm 0.70^{\mathrm{a}}$ & $7.10 \pm 0.50^{\mathrm{a}}$ & $7.17 \pm 0.34^{\mathrm{a}}$ \\
\hline Fib $\left(\mathrm{mg} \mathrm{dL}^{-1}\right)$ & $383.33 \pm 102.99^{\mathrm{a}}$ & $314.29 \pm 102.71^{\mathrm{a}}$ & $361.54 \pm 96.08^{\mathrm{a}}$ & $338.46 \pm 96.08^{\mathrm{a}}$ \\
\hline Leuco $\left(\mathrm{x} 10^{3} \mu \mathrm{L}^{-1}\right)$ & $11.15 \pm 1.56^{\mathrm{a}}$ & $10.15 \pm 2.28^{\mathrm{a}}$ & $10.38 \pm 1.28^{\mathrm{a}}$ & $11.19 \pm 1.74^{\mathrm{a}}$ \\
\hline $\operatorname{Seg}\left(x 10^{3} \mu \mathrm{L}^{-1}\right)$ & $5.26 \pm 0.94^{\mathrm{a}}$ & $5.14 \pm 2.12^{\mathrm{a}}$ & $5.37 \pm 1.16^{\mathrm{a}}$ & $5.75 \pm 1.36^{\mathrm{a}}$ \\
\hline Band $\left(x 10^{3} \mu \mathrm{L}^{-1}\right)$ & $0.00 \pm 0.00^{\mathrm{a}}$ & $0.00 \pm 0.00^{\mathrm{a}}$ & $0.00 \pm 0.00^{\mathrm{a}}$ & $0.00 \pm 0.00^{\mathrm{a}}$ \\
\hline Lympho $\left(\mathrm{x} 10^{3} \mu \mathrm{L}^{-1}\right)$ & $5.23 \pm 0.90^{\mathrm{a}}$ & $4.37 \pm 0.89^{\mathrm{a}}$ & $4.42 \pm 0.96^{\mathrm{a}}$ & $4.34 \pm 1.08^{\mathrm{a}}$ \\
\hline Mono $\left(\times 10^{3} \mu \mathrm{L}^{-1}\right)$ & $0.13 \pm 0.09^{\mathrm{a}}$ & $0.10 \pm 0.10^{\mathrm{a}}$ & $0.07 \pm 0.08^{\mathrm{a}}$ & $0.13 \pm 0.14^{\mathrm{a}}$ \\
\hline $\operatorname{Eosi}\left(\times 10^{3} \mu \mathrm{L}^{-1}\right)$ & $0.39 \pm 0.24^{\mathrm{b}}$ & $0.52 \pm 0.60^{\mathrm{ab}}$ & $0.50 \pm 0.36^{\mathrm{ab}}$ & $0.95 \pm 0.64^{\mathrm{a}}$ \\
\hline Baso $\left(x 10^{3} \mu \mathrm{L}^{-1}\right)$ & $0.00 \pm 0.00^{\mathrm{a}}$ & $0.02 \pm 0.04^{\mathrm{a}}$ & $0.02 \pm 0.04^{\mathrm{a}}$ & $0.02 \pm 0.04^{\mathrm{a}}$ \\
\hline $\mathrm{N}: \mathrm{L}$ & $1.04 \pm 0.31^{\mathrm{a}}$ & $1.21 \pm 0.49^{\mathrm{a}}$ & $1.31 \pm 0.54^{\mathrm{a}}$ & $1.40 \pm 0.46^{\mathrm{a}}$ \\
\hline
\end{tabular}

${ }^{a, b}$ For the same lowercase letters, there is no significant difference $(\mathrm{P}<0.05)$ between the groups.

${ }^{\mathrm{ab}}$ For the different lowercase letters, there is significant difference $(\mathrm{P}>0,05)$ between the groups.

which were attributed to the low iron concentrations found in this age group. When analyzing the WBC, significantly higher values $(\mathrm{P}<0.05)$ were noted for the total number of eosinophils in horses over 13 years of age; however, no explanation for this variation was found in the literature referenced. DÍAZ et al. (2011) observed significantly higher values for the total number of eosinophils in young horses than in adults over the age of three. Results for total protein and plasma fibrinogen were not influenced by age in this study. Several authors (VEIGA et al., 2006; MORUZZI et al., 2007; HOWARD et al., 2008; RIBEIRO et al., 2008; DIAZ et al., 2011) working with different breeds observed greater influence attributable to age in the hematological values of young horses. In the Campeiro horses, this physiological behavior could not be assessed because only adult horses were used in this research as the horses needed to be registered in the ABRACC, which requires the horses to be tamed and to undergo morphometric, behavioral, and gait evaluations, the latter being a mandatory characteristic. As the taming of these horses is only completed after they are three years of age, the youngest horses studied were at minimum three years old.

\section{CONCLUSION}

According to the results obtained in this study, it can be concluded that the analysis of the blood count and plasma fibrinogen of the Campeiro horses reveals specificities compared to other breeds. Thus, these results could be used as benchmarks for the evaluation of these variables in Campeiro horses.

\section{ACKNOWLEDGMENTS}

To Programa de Bolsas de Iniciação Científica (PROBIC) and Programa Institucional Voluntário de Iniciação Científica (PIVIC) of Universidade do Estado de Santa Catarina (UDESC) for research fellowship of Renan Menegasso Bagio and Marcio Luiz Ceccatto.

\section{COMMITTEE ON ETHICS AND BIOSAFETY}

Registration n. 1.26.11

\section{REFERENCES}

ARAÚJO, R.V. Os Jesuítas dos sete povos. Canoas: La Salle, 1990. $467 \mathrm{p}$.

ABRACCC 2013. Cavalo Campeiro - Histórico. Available from: $<$ http://cavalocampeiro.com/cavalo-campeiro/historico/>. Accessed: Feb. 07, 2013.

Ciência Rural, v.46, n.1, jan, 2016. 
BALARIN, M.R.S. et al. Assessement of glycaemia and serum activities of aspartate aminotransferase, creatinekinase, gamma glutamyltransferase and lactate dehydrogenase in thoroughbred horses submitted to exercise of different intensities. Semina: Ciências Agrárias, v.26, n.2, p.211-218, 2005. Available from: $<$ http://dx.doi.org/10.5433/1679-0359.2005v26n2p211>. Accessed: Feb. 05, 2014. doi: 10.5433/1679-0359.2005v26n2p211.

BICALHO, H.M.S. Grupos sangüíneos e polimorfismos de proteínas do sangue da raça Caracu (Bos taurus taurus). Análise populacional. 1985. 114f. Dissertação (Mestrado em Zootecnia) - Curso de Pós-graduação em Zootecnia, Universidade Federal de Minas Gerais, MG

CARRICK, J.B.; BEGG, A.P. Peripheral blood leukocytes. Veterinary Clinic of North America: Equine Practice, v.24, n.2, p.239-259, 2008. Available from: <http://dx.doi.org 10.1016/j. cveq.2008.05.003>. Acceced: Feb. 06, 2014. doi: 10.1016/j. cveq.2008.05.003.

COSTA, A.P.D. et al. Hemogram of racehorses in races of 1300 meters. Revista de Ciências da Vida, v.29, n.2, p.01-08, 2009. Available from: <http://www.ufrrj.br/SEER/index.php?journal= rcv\&page $=$ article \&op=view\&path[] $=93 \&$ path[] $=58>$. Accessed: Feb. 05, 2014.

CURI, P.R. Metodologia e análise da pesquisa em ciências biológicas. 2.ed. Botucatu: Tipomic, 1998. 263p.

DÍAZ, G.H. et al. Hematologic values, bilirubin and enzymeactivities in serum of peruvian paso horses from Lurin valley, Lima. Revista Investigaciones Veterinarias del Perú, v.22, n.3, p.213-222, 2011. Available from: <http://www.scielo. org.pe/scielo.php?pid=S1609-91172011000300006\&script $=$ sci arttext>. Accessed: Feb. 12, 2014.

DOSSIN, O. Usual values of biochemical, hematological and plasma constituents of saddle horses. Revue de Médecine vétérinaire, v.144, n.6, p.543-551, 1993.

HARVEY, J.W. et al. Haematology of foals up to one year old. Equine Veterinary Journal, v.16, n.4, p.347-353, 1984. Available from: <http://dx.doi.org/10.1111/j.2042-3306.1984.tb01940.x>. Accessed: Feb. 06, 2014. doi: 10.1111/j.2042-3306.1984.tb01940.x.

HOLANDA, L.C. et al. Hematological variables of horses (Equus caballus Linnaeus, 1958) breed Mangalarga Marchador. Medicina Veterinária, v.7, n.3, p.1-6, 2013. Available from: <http://revista. dmv.ufrpe.br/index.php/rdmv/article/view/304/171>. Accessed: Feb. 06, 2014.

HOWARD, D.L. et al. Total protein, albumin and globulin of healthy developing Brazilian Sport Horse (Brasileiro de Hipismo) fillies. Ars Veterinaria, v.24, n.2, p.077-082, 2008. Available from: $<$ http://dx.doi.org/10.15361/2175-0106.2008v24n2p77-82>. Feb. 10, 2014. doi: 10.15361/2175-0106.2008v24n2p77-82.

JAIN, N.C. Essentials of veterinary hematology. Philadelphia: Lea \& Febiger, 1993. 417p.

GRONDIN, T.M.; DEWITT, S.F. Normal hematology of the horse and donkey. In: WEISS, D.J.; WARDROP, K.J. Schalm's veterinary hematology. 6.ed. Ames: Wiley-Blackwell, 2010. p.821-828.
KANEKO, J.J. et al. Clinical biochemistry of domestic animals. 6.ed. San Diego: Academic, 2008. 916p.

LACERDA, L. et al. Hematologic and biochemical parameters in three high performance horse breeds from southern Brazil. Archives of Veterinary Science, v.11, n.2, p.40-44, 2006. Available from: $<$ http://www.ufrgs.br/lacvet/restrito/pdf/lacerda_3horse_breeds. pdf>. Accessed: Feb. 15, 2014.

LATIMER, K.S.; PRASSE, K.W. Leukocytes. In: LATIMER, K.S. et al. Duncan and Prasse's veterinary laboratory medicine clinical pathology. 4.ed. Ames: Iowa State, 2003. p.46-79.

LOPES, S.T.A. et al. Manual de patologia clínica veterinária. 3.ed. Santa Maria: UFSM, 2007. 107p.

MARTINS, C. et al. Biochemical parameters in horses before and after endurance competition. Revista Brasileira de Ciência Veterinária, v.12, p.62-65, 2005. Available from: <http://www. uff.br/rbcv/ojs/index.php/rbcv/article/view/525/pdf>. Accessed: Feb 10, 2014.

McMANUS, C. et al. Morphological Characterization of the Campeiro Horse Breed. Revista Brasileira de Zootecnia, v.34, n.5, p.1553-1562, 2005. Available from: <http://www.scielo.br/ pdf/rbz/v34n5/26635.pdf>. Accessed: Feb. 10, 2014.

MORUZZI, M.M. et al. Haematological parameters in Arabian foals. Ars Veterinária, v.23, n.3, p.129-133, 2007. Available from: $<$ http://dx.doi.org/10.15361/2175-0106.2007v23n3p129-133>. Feb. 12, 2014. doi: 10.15361/2175-0106.2007v23n3p129-133.

RALSTON, S.L. et al. Differences in diagnostic test results and hematologic data between aged and young horses. American Journal Veterinary Research, v.49, n.8, p.1387-1392, 1988. Available from: <http://europepmc.org/abstract/med/3052193. pdf $>$. Accessed: Feb. 12, 2014.

RIBEIRO, C.R. et al. Hematological profile of healthy Pantaneiro horses. Arquivo Brasileiro de Medicina Veterinária e Zootecnia, v.60, n.2, p.492-495, 2008. Available from: <http:// dx.doi.org/10.1590/S0102-09352008000200033>. Feb. 10, 2014. doi: $10.1590 / \mathrm{S} 0102-09352008000200033$

SILVA, H.I.S.B. Contribuição para o estudo do hemograma do cavalo Puro Sangue Lusitano. 2011. 78f. Dissertação (Mestrado em Medicina Veterinária) - Curso de Pós-graduação em Medicina Veterinária, Universidade de Lusófona de Humanidades e Tecnologias. Available from: $<\mathrm{http}: / /$ recil.grupolusofona.pt/bitstream/ handle/10437/1580/Disserta\%C3\%A7ao_de_Mestrado_-_Helena_ Silva.pdf?sequence=1>. Accessed: Feb. 12, 2014.

TAYLOR-MACALLISTER, C. Haematology and serum biochemistry evaluation in normal postpartum mares. Equine Veterinary Journal, v.29, n.3, p.234-235, 1997. Available from: $<$ http://dx.doi.org/10.1111/j.2042-3306.1997.tb01675.x >. Accessed: Feb. 10, 2014. doi: 10.1111/j.2042-3306.1997.tb01675.x.

VEIGA, A.P.M. et al. Hematological values, plasma protein and fibrinogen of criollo horse - their variation with sex, age and management. Acta Scientiae Veterinariae, v.34, n.3, p.275279, 2006. Available from: <http://www.ufrgs.br/actavet/34-3/ artigo687.pdf $>$. Accessed: Feb. 12, 2014. 